\title{
Assessment of Seed Hardening on Morpho-physiological and Yield Parameters of Mustard (Brassica juncea L.)
}

\author{
Elakoti Krishna Reddy ${ }^{1 *}$, Abhinav Dayal' ${ }^{2}$ Prashant Kumar Rai ${ }^{2}$ and M. Raghava ${ }^{1}$ \\ ${ }^{1}$ Department of Seed Science and Technology, ${ }^{2}$ Department of Genetics and Plant Breeding, \\ Naini Agricultural Institute, Sam Higginbottom University of Agriculture, Technology and \\ Sciences, Prayagraj, Uttar Pradesh, India
}

*Corresponding author

\section{A B S T R A C T}

The present investigation was carried out for assessment of seed hardening on morphophysiological and yield parameters of mustard (Brassica juncea L.). For this purpose, twelve seed hardening treatments including control on mustard seeds variety (T-59) were used to study under filed conditions during Rabi, 2019-20 field experiment was laid out in Randomized Block Design (RBD) with three replications during Rabi 2019-20.Analysis for the data in field experiment revealed significance mean sum of squares due to seed hardening treatments for all the characters under study. The treatment were T0 - Control, T1 - Potassium nitrate $\left(\mathrm{KNO}_{3}\right) 2 \% @ 12 \mathrm{hrs}, \mathrm{T} 2$ - Zinc sulphate $\left(\mathrm{ZnSO}_{4}\right) 2 \%$ @ 12hrs, T3 Calcium chloride $(\mathrm{CaCl} 2) 2 \%$ @12hrs, T4 - Mono potassium phosphate $\left(\mathrm{KH}_{2} \mathrm{PO}_{4}\right) 2 \%$ @ $12 \mathrm{hrs}, \mathrm{T} 5$ - Potassium chloride $(\mathrm{KCl}) 2 \%$ @ $12 \mathrm{hrs}, \mathrm{T} 6$-Gibberellic acid $\left(\mathrm{GA}_{3}\right) 2 \%$ @12hrs, T7 - Indole Acetic Acid (IAA)2\% @12hrs, T8 - Pungam leafextract2\% @12hrs, T9 -Prosopsis leaf extract 2\%@12hrs, T10 -Neem leaf extract5\%@12hrs, T11 -Cow dung10\%@12hrs, T12 -Panchagavya3\% @12hrs.Maximum field emergence, leaf dry weight, leaf area was recorded in T3-Cacl2(2\%) (12hrs). Minimum days to 50\% flowering were recorded in T3. Maximum plant height at 30 DAS $(\mathrm{cm}), 60$ DAS $(\mathrm{cm})$ and 90DAS $(\mathrm{cm})$ and Number of branches per plant was recorded in T3. Number of primary branches, number of secondary branches, number of silique per plant, number of seeds per siliqua, seed yield, test weight, biological yield and harvest index were also recorded high in T3 treatmentcac12@2\% followed by T6-GA3@2\%.

\section{Introduction}

Mustard (Brassica juncea L.) a member of Brassicaceae family and is an important oil seed crop of the world. Mustard belongs to family Brassicaceae or Cruciferae and chromosome number is $2 \mathrm{n}=36$. The Brassica species commonly called as rapeseed-mustard are one of the economically important agricultural commodities (Tripathi et al., 2010).

Indian mustard (Brassica juncea L.) is majorly grown in Rajasthan, UP, Haryana, Madhya Pradesh and Gujarat. It is also grown under some nontraditional areas of south 
India including Karnataka, Tamil Nadu and Andhra Pradesh. The crop can be cultivated under both irrigated and rainfed conditions. Mustard yield potential is good is high and has wider adaptability and has high oil content with good quality.

Indian mustard is nutritionally rich and its oil content vary from $37-49 \%$. The seed and oil are used as a condiment in preparation of pickles, flavouring, curries and vegetables as well as for cooking and frying purposes. Its oil is used in many industrial products, cake as cattle feed and manure and green leaves for vegetable and green fodder.

Mustard seed is the third leading source of vegetable oil in the world after soya bean oil and oil palm oil. Mustard seed containing about $40-50 \%$ protein. It is world's second leading sources of protein meal after soya bean meal.

In India, it is the second most important edible oilseed after groundnut sharing $27.8 \%$ in the oilseed economy (FAO, Stat, 2018).

\section{Materials and Methods}

The experiment was carried out under the field condition during Rabi (2019-20) at field experimental center and seed testing laboratory, Department of Genetics and Plant Breeding, Sam Higginbottom University of Agriculture, Technology \& Sciences, Prayagraj the experiment was laid out in Randomized Block Design with three replications and twelve treatments.

$\mathrm{T} 0=$ Control, $\mathrm{T} 1=$ Potassium nitrate $\left(\mathrm{KNO}_{3}\right)$, $\mathrm{T} 2=$ Zinc sulphate $\left(\mathrm{ZnSO}_{4}\right), \mathrm{T} 3=$ Calcium chloride $(\mathrm{CaCl} 2), \mathrm{T} 4=$ Mono potassium phosphate $\left(\mathrm{KH}_{2} \mathrm{PO}_{4}\right), \quad \mathrm{T} 5=$ Potassium chloride $(\mathrm{KCl}), \mathrm{T} 6=$ Gibberellic acid $\left(\mathrm{GA}_{3}\right)$, T7 = Indole Acetic Acid (IAA), T8 = Pungam leafextract, $\mathrm{T} 9=$ Prosopsis leaf extract $\mathrm{T} 10=$
Neem leaf extract, T11 = Cow dung, T12 = Panchagavya

\section{Results and Discussion}

In different seed hardening treatments T3$\mathrm{CaCl} 2 @ 2 \%$ has performed the best results when compared to all the other seed hardening treatments and the lowest results were showed by control. The T3$\mathrm{CaCl} 2 @ 2 \%$ performed the best results in all the parameters i.e., field emergence (94.04\%), days to $50 \%$ flowering (42.33), plant height 30DAS (18.36), plant height 60DAS(108.02), plant height 90DAS (148.41), number of primary branches per plant (5.56), number of secondary branches (7.30), leaf area (238.64), leaf dry weight (2.10), number of siliqua per plant(111.94), number of seeds per siliqua(12.16), seed yield per plant (5.12), test weight (5.14), biological yield(4904.25), harvest index(23.00) and it was followed by T6-GA3performed the better results in all the parameters i.e., field emergence (93.23), days to $50 \%$ flowering (44.00), plant height 30DAS (17.44), plant height 60DAS(103.46), plant height 90DAS (145.84), number of primary branches per plant (5.00), number of secondary branches (5.80), leaf area (225.07), leaf dry weight (2.04), number of siliqua per plant (108.74), number of seeds per siliqua (12.05), seed yield per plant (4.88), test weight (4.61), biological yield(4874.54), harvest index(21.00)

Seed hardening is one of the best methods that results in modifying the physiological and biochemical characters of seed so this leads to favorable for drought resistant. Seed hardening is the results of extensive physiological reorganization induced by hydration and dehydration (Sujatha et al.,2013). Similar results were found in chickpea, significantly higher seeds yield was recorded in seed treatment with $\mathrm{CaCl} 2-2 \%$ (Table 1). 


\section{Table.1}

\begin{tabular}{|c|c|c|c|c|c|c|c|c|c|c|c|c|c|c|c|c|}
\hline S.No & Treatments & $\begin{array}{c}\text { Field } \\
\text { emer } \\
\text { gence } \\
(\%)\end{array}$ & $\begin{array}{c}\text { Days to } \\
50 \% \\
\text { flowering }\end{array}$ & $\begin{array}{c}\text { Plant } \\
\text { height } \\
\text { at } 30 \\
\text { DAS }\end{array}$ & $\begin{array}{c}\text { Plant } \\
\text { height } \\
\text { at } 60 \\
\text { DAS }\end{array}$ & $\begin{array}{c}\text { Plant } \\
\text { height } \\
\text { at } 90 \\
\text { DAS }\end{array}$ & $\begin{array}{c}\text { No. of } \\
\text { primary } \\
\text { branches } \\
\text { per plant }\end{array}$ & $\begin{array}{c}\text { No. of } \\
\text { secondary } \\
\text { branches } \\
\text { per plant }\end{array}$ & $\begin{array}{c}\text { Leaf area } \\
\left(\mathrm{cm}^{2}\right)\end{array}$ & $\begin{array}{l}\text { Leaf } \\
\text { dry } \\
\text { weight } \\
(\mathrm{g})\end{array}$ & $\begin{array}{c}\text { No. of } \\
\text { siliquae } \\
\text { per } \\
\text { plant }\end{array}$ & $\begin{array}{l}\text { No. of } \\
\text { seeds } \\
\text { per } \\
\text { siliquae }\end{array}$ & $\begin{array}{l}\text { Seed yield } \\
\text { per } \\
\text { plant }(\mathrm{g})\end{array}$ & $\begin{array}{c}\text { Test } \\
\text { Weight } \\
(\mathrm{g})\end{array}$ & $\begin{array}{c}\text { Biological } \\
\text { yield } \\
(\mathrm{Kg} / \mathrm{ha})\end{array}$ & $\begin{array}{c}\text { Harvest } \\
\text { Index } \\
(\%)\end{array}$ \\
\hline 01 & $\mathrm{~T}_{0}$ & 82.02 & 51.33 & 15.14 & 80.19 & 103.20 & 2.80 & 3.20 & 117.68 & 0.95 & 67.36 & 10.13 & 2.80 & 3.39 & 2722.25 & 17.00 \\
\hline 02 & $\mathrm{~T}_{1}$ & 85.57 & 48.66 & 15.69 & 84.56 & 111.52 & 3.33 & 3.56 & 143.39 & 1.35 & 97.71 & 11.39 & 4.04 & 4.25 & 3594.88 & 18.67 \\
\hline 03 & $\mathrm{~T}_{2}$ & 84.23 & 49.00 & 16.33 & 83.91 & 122.83 & 4.66 & 3.26 & 130.51 & 1.82 & 103.43 & 10.73 & 3.78 & 3.43 & 3874.71 & 18.67 \\
\hline 04 & $\mathrm{~T}_{3}$ & 94.05 & 42.33 & 18.36 & 108.02 & 148.41 & 5.56 & 7.30 & 238.64 & 2.10 & 111.94 & 12.16 & 5.12 & 5.14 & 4904.25 & 23.00 \\
\hline 05 & $\mathrm{~T}_{4}$ & 85.78 & 46.66 & 15.94 & 82.14 & 121.15 & 4.0 & 4.06 & 159.35 & 1.94 & 85.25 & 11.33 & 3.88 & 4.26 & 3780.21 & 18.67 \\
\hline 06 & $\mathrm{~T}_{5}$ & 90.39 & 48.00 & 16.61 & 88.62 & 120.87 & 3.53 & 3.53 & 136.69 & 0.98 & 77.43 & 11.59 & 3.76 & 3.51 & 3607.91 & 19.67 \\
\hline 07 & $\mathrm{~T}_{6}$ & 93.23 & 44.00 & 17.44 & 103.46 & 145.84 & 5.00 & 5.80 & 225.07 & 2.04 & 108.74 & 12.05 & 4.88 & 4.61 & 4874.54 & 21.00 \\
\hline 08 & $\mathrm{~T}_{7}$ & 89.97 & 46.00 & 16.31 & 82.11 & 127.79 & 3.40 & 4.73 & 132.82 & 1.90 & 92.35 & 11.48 & 3.85 & 3.60 & 4054.79 & 17.00 \\
\hline 09 & $\mathrm{~T}_{8}$ & 87.84 & 50.33 & 17.13 & 82.44 & 121.58 & 3.93 & 4.06 & 143.24 & 1.73 & 73.81 & 10.39 & 4.08 & 4.27 & 3896.25 & 18.00 \\
\hline 10 & $\mathrm{~T}_{9}$ & 87.14 & 48.00 & 15.67 & 95.77 & 124.16 & 4.00 & 4.40 & 156.82 & 1.53 & 90.14 & 11.36 & 3.39 & 3.65 & 3939.27 & 17.33 \\
\hline 11 & $\mathrm{~T}_{10}$ & 92.57 & 45.66 & 17.28 & 100.07 & 132.87 & 4.96 & 5.00 & 198.84 & 2.02 & 105.24 & 11.73 & 4.44 & 4.35 & 4066.41 & 18.67 \\
\hline 12 & $\mathrm{~T}_{11}$ & 86.77 & 49.66 & 17.10 & 82.17 & 120.11 & 3.80 & 4.20 & 138.16 & 1.49 & 102.93 & 10.26 & 3.45 & 4.03 & 3508.88 & 17.33 \\
\hline 13 & $\mathrm{~T}_{12}$ & 82.71 & 49.33 & 15.52 & 86.13 & 116.84 & 3.83 & 3.63 & 155.43 & 1.04 & 84.66 & 11.41 & 3.02 & 4.10 & 3693.36 & 18.00 \\
\hline \multicolumn{2}{|c|}{ Grand Mean } & 87.86 & 47.61 & 16.50 & 89.19 & 123.63 & 4.06 & 4.36 & 155.82 & 1.60 & 92.38 & 11.23 & 3.88 & 4.04 & 3886.05 & 18.69 \\
\hline \multicolumn{2}{|r|}{ F test } & S & S & S & S & S & S & S & NS & $\mathrm{S}$ & NS & $\mathrm{S}$ & $\mathrm{S}$ & S & NS & S \\
\hline \multicolumn{2}{|r|}{$\mathrm{SE}(\mathrm{m})$} & 0.953 & 0.804 & 0.902 & 1.00 & 1.68 & 0.135 & 0.15 & 8.29 & 1.07 & 2.43 & 0.74 & 0.154 & 0.539 & 341.91 & 0.5 \\
\hline \multicolumn{2}{|c|}{$\mathrm{CD}$ at $5 \%$} & 2.814 & 2.37 & 2.25 & 2.97 & 4.97 & 0.39 & 0.47 & 17.49 & 0.22 & 6.19 & 1.29 & 0.454 & 4.25 & 109.21 & 1.7 \\
\hline \multicolumn{2}{|r|}{ C.V, } & 1.871 & 2.93 & 2.418 & 3.95 & 2.34 & 1.01 & 2.67 & 7.78 & 1.97 & 3.54 & 2.72 & 4.724 & 1.18 & 8.54 & 2.4 \\
\hline
\end{tabular}


Drought tolerance capacity of chickpea seed was increased by seed hardening with CaCl2@2\% (Manjunath, et al., 2010). Some other authors are also found similar results i.e., maximum increase in growth, yield and seed vigour traits when chickpea seeds are hardening with $\mathrm{CaCl} 2 @ 2 \%$ (Akshay Kunghatkar et al., 2018). Similar seed hardening results were obtained in growth and yield parameters when blackgram seeds are imposed with various seed hardening treatment. They concluded that prosopis@1\% recorded the highest seed yield and yield attributing characters compared to other treatments and control under drought conditions (Sathiya Narayanan, G. 2016).Some others also found the similar results i.e., pre sowing seed hardening treatment $\mathrm{CaCl}_{2} @ 1 \%$ significantly increased the yield attributing characters when compared to control in case of rice crop. (Satheesh Kumar et al., 2019).

The overall performance of treatments under study judged on the basis of positive results obtained indicated the treatments $\mathrm{T}_{3}\left(\mathrm{CaCl}_{2} @\right.$ $2 \%)$ and $\mathrm{T}_{6}\left(\mathrm{GA}_{3} @ 2 \%\right)$ had performed well with respect to morpho-physiological, plant growth and seed yield parameters. The fore cited treatments found to be promising than other treatments.

The treatment $\mathrm{T}_{3}\left(\mathrm{CaCl}_{2} @ 2 \%\right)$ recorded (5.14 g 1000 seed weight), (biological yield of $4905.25 \mathrm{Kg} / \mathrm{ha}$ ) and (harvest Index of 23\%) found to be most promising amongst the treatments considered for the experiment. The effect of at par treatments $\mathrm{T}_{6}\left(\mathrm{GA}_{3} @ 2 \%\right)$ and $\mathrm{T}_{10}$ (Neem leaf extract @ 5\%) were also found to be good as seed primers in case of Mustard.

\section{References}

Akshay Kunghatkar. L., Chaurasia. A. K., Bineeta. M. Bara., and Surya Prakash
Meena. (2018). Influence of seed hardening techniques on vigour, growth and yield in chickpea [Cicer arietinum (L.)]. The Pharma Innovation Journal. 2018; 7(7): 528-531

Chauhan, J. S, Prasad, S. R., Pal, S., Choudhury, P. R. and Udayabhaskar, K. 2016. Seed production of field crops in India: Quality assurance, status, impact and way forward. Indian Journal of Agricultural Sciences, 86 (5): 563-579.

Geetha, R. and Selvakumari, A. (2007) Effect of seed hardening and pelleting in sorghum under rainfed condition. Inter. J. Pl. Sci., 3(2): 610-612

Karivaratharaju, T.V. and V. Ramakrishnan. (2015). Seed hardening studies in two varieties of ragi (Eueusine coracana). Indian J. Pl. Physiology. 28: 243-248.

Manjunath, B. L. and Dhanoji, M. M., (2010). Effect of seed hardening with chemicals on drought tolerance traits and yield in chickpea (Cicer arietinum L.). Journal of Agricultural Sciences. 3 (3) (4-8)

Mahbeer Meena, Arun A david and Sanjeev Kumar (2018). Effect of different leve;s of Zinc amd NPK on yield and oil content of Mustard (Brasiica uncea L) Var Jai Kisan. International Journal of Pure and Applied Biosciences.6 (6) 722-727.

Piri, K.L., P. Srimathi, N. Mariappan, L. Sundaramoorthy and M. Paramathma. (2013). Efficacy of Panchagavyaon seed invigoration of bio fuel. Crops Sciences Research. Essays 8(41): 20312037

Satheesh Kumar P, Kamaraj A, Suganthi S, Prabhu T (2019) Effect of pre sowing seed hardening treatment on seed quality, crop growth and seed yield in rice cv. IR64 Journal of Pharmacognosy and Phytochemistry SP2 : 594-597

Sathiya Narayanan, G. Prakash, M. and Reka, M. (2016) Influence of seed hardening 
treatments on growth, gas exchange and yield parameters in black gram under drought condition. Legume Research, 39 (2): 248-255.

Suchitra Rakesh, S. Pooonguzhali, B. Saranya, Suguna and K. Jothibasu (2017) Effects of panchagavya on growth and yield of Abelmoschus esculentus Arka Anamika. International Journal of Current Microbiology Applied Sciences 6(9):3090-3097.

Sujatha K, Sivasubramanaiam K, Padma J, Selvarani K. (2013) Seed hardening.
Indian Journal of Agricultural Sciences 9(1):67-73.

Tripathi, M. K., Chaturvedi, S., Shukla, D. K. and Mahapatra, B. S. (2010). Yield performance and quality in Indian mustard (Brassica junceai) as affected by integrated nutrient management. Indian Journal of Agronomy. 55(20:138-142.

Vijaya, J. (2016). Standardization of presowing seed management technique for pulses. M.Sc. (Ag.) Thesis. Tamil Nadu Agriculture University, Coimbatore.

\section{How to cite this article:}

Elakoti Krishna Redd, Abhinav Dayal, Prashant Kumar Rai and Raghava, M. 2021. Assessment of Seed Hardening on Morpho-physiological and Yield Parameters of Mustard (Brassica juncea L.). Int.J.Curr.Microbiol.App.Sci. 10(02): 1879-1883. doi: https://doi.org/10.20546/ijcmas.2021.1002.222 